\title{
Heated submicron particle fluxes using an optical particle counter in urban environment
}

\author{
M. $\operatorname{Vogt}^{1}$, C. Johansson ${ }^{1,2}$, M. Mårtensson ${ }^{1,3}$, H. Struthers ${ }^{1,4,5}$, L. Ahlm ${ }^{1}$, and D. Nilsson ${ }^{1}$ \\ ${ }^{1}$ Department of Applied Environmental Science (ITM), Stockholm University, 10691 Stockholm, Sweden \\ ${ }^{2}$ City of Stockholm Environment and Health Administration, P.O. Box 8136, 10420 Stockholm, Sweden \\ ${ }^{3}$ Department of Earth Sciences, Uppsala University, 75236 Uppsala, Sweden \\ ${ }^{4}$ Department of Meteorology, Stockholm University, 10691 Stockholm, Sweden \\ ${ }^{5}$ Bert Bolin Centre for Climate Research, Stockholm University, Stockholm, Sweden
}

Correspondence to: M. Vogt (matthias.vogt@ helsinki.fi)

Received: 4 August 2011 - Published in Atmos. Chem. Phys. Discuss.: 20 September 2011

Revised: 11 February 2013 - Accepted: 20 February 2013 - Published: 15 March 2013

\begin{abstract}
From May 2008 to March 2009 aerosol emissions were measured using the eddy covariance method covering the size range 0.25 to $2.5 \mu \mathrm{m}$ diameter $\left(D_{\mathrm{p}}\right)$ from a $105 \mathrm{~m}$ tower, in central Stockholm, Sweden. Supporting chemical aerosol data were collected at roof and street level. Results show that the inorganic fraction of sulfate, nitrate, ammonium and sea salt accounts for approximately $15 \%$ of the total aerosol mass $<1 \mu \mathrm{m} D_{\mathrm{p}}\left(\mathrm{PM}_{1}\right)$ with water soluble soil contributing $11 \%$ and water insoluble soil $47 \%$. Carbonaceous compounds were at the most $27 \%$ of $\mathrm{PM}_{1}$ mass. It was found that heating the air from the tower to $200{ }^{\circ} \mathrm{C}$ resulted in the loss of approximately $60 \%$ of the aerosol volume at $0.25 \mu \mathrm{m} D_{\mathrm{p}}$ whereas only $40 \%$ of the aerosol volume was removed at $0.6 \mu \mathrm{m} D_{\mathrm{p}}$. Further heating to $300^{\circ} \mathrm{C}$ caused very little additional losses $<0.6 \mu \mathrm{m} D_{\mathrm{p}}$. The chemical analysis did not include carbonaceous compounds, but based on the difference between the total mass concentration and the sum of the analyzed non-carbonaceous materials, it can be assumed that the non-volatile particulate material (heated to $300^{\circ} \mathrm{C}$ ) consists mainly of carbonaceous compounds, including elemental carbon. Furthermore, it was found that the nonvolatile particle fraction $<0.6 \mu \mathrm{m} D_{\mathrm{p}}$ correlated $\left(r^{2}=0.4\right)$ with the $\mathrm{BC}$ concentration at roof level in the city, supporting the assumption that the non-volatile material consists of carbonaceous compounds. The average diurnal cycles of the $\mathrm{BC}$ emissions from road traffic (as inferred from the ratio of the incremental concentrations of nitrogen oxides $\left(\mathrm{NO}_{\mathrm{x}}\right)$ and $\mathrm{BC}$ measured on a densely trafficked street) and the fluxes of non-volatile material at tower level are in close agreement,
\end{abstract}

suggesting a traffic source of $\mathrm{BC}$. We have estimated the emission factors (EFs) for non-volatile particles $<0.6 \mu \mathrm{m} D_{\mathrm{p}}$ to be $2.4 \pm 1.4 \mathrm{mg} \mathrm{veh}^{-1} \mathrm{~km}^{-1}$ based on either $\mathrm{CO}_{2}$ fluxes or traffic activity data. Light (LDV) and heavy duty vehicle (HDV) EFs were estimated using multiple linear regression and reveal that for non-volatile particulate matter in the 0.25 to $0.6 \mu \mathrm{m} D_{\mathrm{p}}$ range, the $\mathrm{EF}_{\mathrm{HDV}}$ is approximately twice as high as the $\mathrm{EF}_{\mathrm{LDV}}$, the difference not being statistically significant.

\section{Introduction}

Aerosols affect both climate and human health and are therefore a focus of research in environmental science. In particular, aerosols affect the Earth's temperature and climate by changing the radiative properties of the atmosphere. The current best estimate of the total anthropogenic direct aerosol radiative forcing derived from models and observations is $-0.5 \pm 0.4 \mathrm{~W} \mathrm{~m}^{-2}$ (IPCC, 2007). One of the most important components of anthropogenic aerosols is BC, which is a primary aerosol emitted from fossil fuel combustion and biomass burning. It efficiently absorbs visible sunlight and therefore heats the Earth's atmosphere. The direct radiative forcing from fossil fuel $\mathrm{BC}$ is estimated to be $+0.2 \pm 0.15 \mathrm{~W} \mathrm{~m}^{-2}$ (IPCC, 2007). In addition, soot deposited on snow and ice can change the surface albedo and cause a change in the surface radiation balance (Hansen and Nazarenko, 2004). Beside its radiative forcing on climate, 
atmospheric PM, particularly of anthropogenic origin, has been associated with adverse health effects in humans (e.g., Chow et al., 2006). When considering plausible mechanisms of toxicity, the prevailing opinion is that the observed health effects are more strongly linked to the physical or chemical properties of PM rather than the PM mass (NRC, 2004). Several studies have attempted to link particle toxicity with aerosol physical and/or chemical characteristics such as particle size, number concentration and chemical composition. One chemical constituent being studied closely in this regard is BC (e.g., Mar et al., 2000; Peel et al., 2007), particularly given that high concentrations of $\mathrm{BC}$ have been measured in urban areas (Suglia et al., 2008; Krecl et al., 2011). Chemical analysis of measurements taken in urban areas suggests that $\mathrm{BC}$ contributes $5-10 \%$ to $\mathrm{PM}_{2.5}$ (Putaud et al., 2004). The reason for this is that in an urban environment, vehicular emissions (fossil fuel combustion) are one of the major sources of PM (Gidhagen et al., 2003). A significant amount of the particles are emitted from tailpipes, and generated through wear and tear of brake linings (Sternbeck et al., 2002; Södin et al., 2009). For the tailpipe emissions, the particle structure can be thought of as having two components: a semi-volatile fraction arising from vapor to particle condensation upon cooling in or near the tailpipe, and a non-volatile fraction created within the engine in particle form (Sakurai et al., 2003). An open question remains as whether the nonvolatile or semi-volatile material is more toxic. Identification and quantification of the non-volatile and semi-volatile aerosol load would allow for better targeting of abatement strategies beneficial for public health. One method that can be used to help distinguish sub-fractions of the aerosol is the so called "volatility method". In this method, the aerosol is heated in different temperature stages and the number concentration and size of the particles is detected by an Optical Particle Counter (OPC) (O'Dowd and Smith, 1993; Hoppel et al., 1990; Clarke et al., 2004) or other particle sizing instruments like Tandem Differential Mobility Analyzers (TDMA) (e.g., Kuhn et al., 2005; Sakurai et al., 2003; Orsini et al., 1999) or Aerosol Time-Of-Flight Mass Spectrometers (ATOFMS) (Pratt and Prather, 2009). This technique can be used to gain an indirect insight into the main characteristics of aerosol composition. In this paper, we combine volatility measurements with the eddy covariance method not only to gain an insight on aerosol chemistry but also of particle sources and sinks. This paper is the fourth contribution based on a data set measured between 2008 and 2009 in Stockholm, Sweden. Earlier publications characterized the seasonal and diurnal variations of particle fluxes (Vogt et al., 2011a), the relationship between aerosol and $\mathrm{CO}_{2}$ emissions and quantification of emission factors (Vogt et al., 2011b), and emission velocities (Vogt et al., 2011c). This paper addresses the volatile and refractory (non-volatile) fractions of the observed urban aerosol emissions.

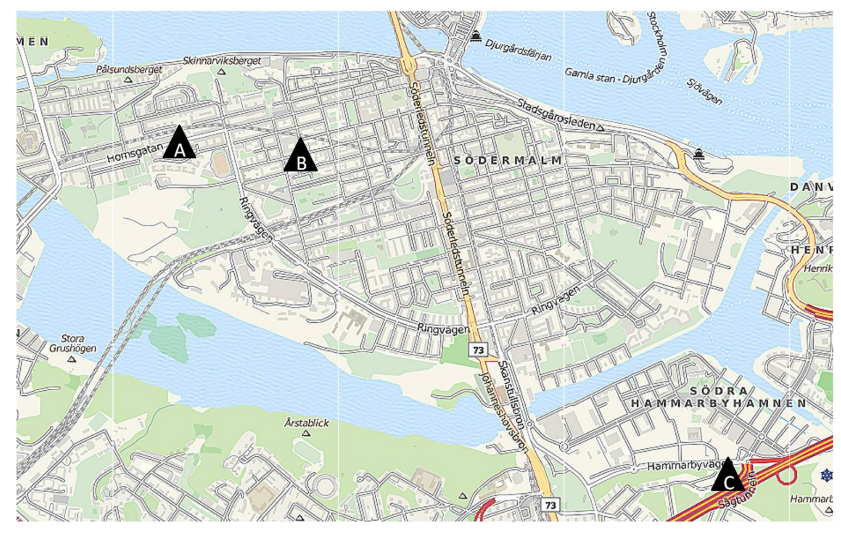

Fig. 1. Location of the monitoring stations in Stockholm: Hornsgatan (A), Torkel Knutssonsgatan (B) and Kalmgatan (C) Blue indicates water surfaces, green forest/park areas, grey built-up areas and red yellow important roads.

\section{Measurement description}

\subsection{Sampling sites}

We make use of data measured at three sites in central Stockholm, in a street canyon (Hornsgatan), on a roof top representing the urban background/roof top (Torkel Knutssonsgatan) and on top of a telecommunications tower (Kalmgatan). Hornsgatan is a four-lane $24 \mathrm{~m}$ wide street-canyon with $24 \mathrm{~m}$ high buildings on both sides, and an average traffic volume of 35000 vehicles per day. The site at Hornsgatan has been described in several earlier papers (Gidhagen et al., 2003; Johansson, 2009; Omstedt et al., 2005; Ketzel et al., 2007; Olivares et al., 2008; Krecl et al., 2011). The instruments at Torkel Knutssonsgatan are located on a rooftop platform ( $25 \mathrm{~m}$ above street level) and therefore represents urban background concentrations for the Stockholm region (described previously by Johansson, 2009). The measurements made at Kalmgatan were from the top of a telecommunications tower in the southern central part of the city. The tower is of concrete construction, $90 \mathrm{~m}$ tall and located $28 \mathrm{~m}$ above the sea level. Based on an elevated platform, the measurements were made $105 \mathrm{~m}$ above the surrounding ground. The tower is located just south of Hammarby Fabriksväg, a local road supporting around 9700 vehicles per day. This road connects to Södra Länken, a heavily trafficked underground freeway tunnel, supporting around 50000 vehicles per day, with one exit located to the Northeast of the tower (Fig. 1). The site has been previously described by Mårtensson et al. (2006) and Vogt et al. (2011a,b,c) . 


\subsection{Instruments and measurement setup}

\subsubsection{Chemical $\mathrm{PM}_{1}$ sampling and $\mathrm{BC}$ analysis at the street canyon and roof-top sites}

Identical aethalometers series 8100 (Magee Scientific, USA) were used to obtain BC concentrations on Hornsgatan (3.5 m above ground in the street canyon) and Torkel Knutssonsgatan (roof top). These instruments were operated with $\mathrm{PM}_{2.5}$ sample inlets and a sample flow rate of $2 \mathrm{~L} \mathrm{~min}^{-1}$. 15 -min average values were logged by the acquisition system. Aethalometer concentrations were computed using the mass specific attenuation cross section provided by the manufacturer $\left(16.6 \mathrm{~m}^{2} \mathrm{~g}^{-1}\right)$. More details can be found in Krecl et al. $(2007,2011)$. At the same sites concentrations of $\mathrm{NO}_{\mathrm{x}}$ were measured based on chemiluminescence (Gidhagen et al., 2004a). At both Hornsgatan and Torkel Knutssonsgatan, parallel sampling on Teflon filters $(25 \mathrm{~mm}$ pore size $1 \mu \mathrm{m}$ ) was made on a $24 \mathrm{~h}$ basis changing at midnight. Six auto-changers were used at each site with each auto-changer being connected to eight sampling heads with a flow rate of $18 \mathrm{~L} \mathrm{~min}^{-1}$. Sampling heads for particles $<1 \mu \mathrm{m} D_{\mathrm{p}}\left(\mathrm{PM}_{1}\right)$ were made of polyoximethylene and had a greased impactor to remove particles larger than $1 \mu \mathrm{m} D_{\mathrm{p}}$. The aerosol filter samples were analyzed for 39 elements using Mass Spectrometry (ICP-MS) (Perkin-Elmer Sciex Elan 6000) and water soluble compounds $\left(\mathrm{Ca}^{2+}, \mathrm{Mg}^{2+}, \mathrm{K}^{+}, \mathrm{Na}^{+}, \mathrm{Cl}^{-}, \mathrm{NH}_{4}^{+}\right.$, $\mathrm{SO}_{4}^{2-}, \mathrm{NO}^{3-}$ ) using ion chromatography (IC). More details about filter preparation, extraction, chemical analysis and the setup can be found in Södin et al. (2009).

\subsubsection{Aerosol concentration, volatility and fluxes of refractory particles and $\mathrm{CO}_{2}$ at the tower site}

The instrumentation in the tower (Kalmgatan) consists of a Gill R3 ultrasonic anemometer, an open path infrared $\mathrm{CO}_{2} / \mathrm{H}_{2} \mathrm{O}$ analyzer LI-COR 7500 (LI-COR, Inc., Lincoln, Nebraska 68504, USA), and two identical OPCs (Model, 1.109, Grimm Ainring, Bayern, Germany). All instruments were placed inside a housing with the sampling point 105 $\mathrm{m}$ above the ground. In order to sample data from the 1.109 $\mathrm{OPC}$ at the maximum rate of $1 \mathrm{~Hz}$ we could only sample either the 15 smallest $\left(0.25-2.5 \mu \mathrm{m} D_{\mathrm{p}}\right)$ or 15 largest (2.5 to $32 \mu \mathrm{m} D_{\mathrm{p}}$ ) size channels of the OPC. In this study we have operated both OPCs at (for 0.25 to $2.5 \mu \mathrm{m} D_{\mathrm{p}}$ ). The OPCs were equipped with a system to heat the inlet air (Grimm Model 265, special version up to $300^{\circ} \mathrm{C}$ ). The sampled air was dried by $1: 1$ dilution with close to $0 \%$ humidity particle free air (detailed information can be found in Vogt et al. (2011a). Figure 2 illustrates the setup of the instrumentation. The heater efficiency of the commercial Grimm Model 265 was tested with Ammonium sulfate particles where it was found that the heater effectively removed all particles at temperatures of $300{ }^{\circ} \mathrm{C}$, even for particle number concentrations as high as approximately 10000 particles $\mathrm{cm}^{3}$.

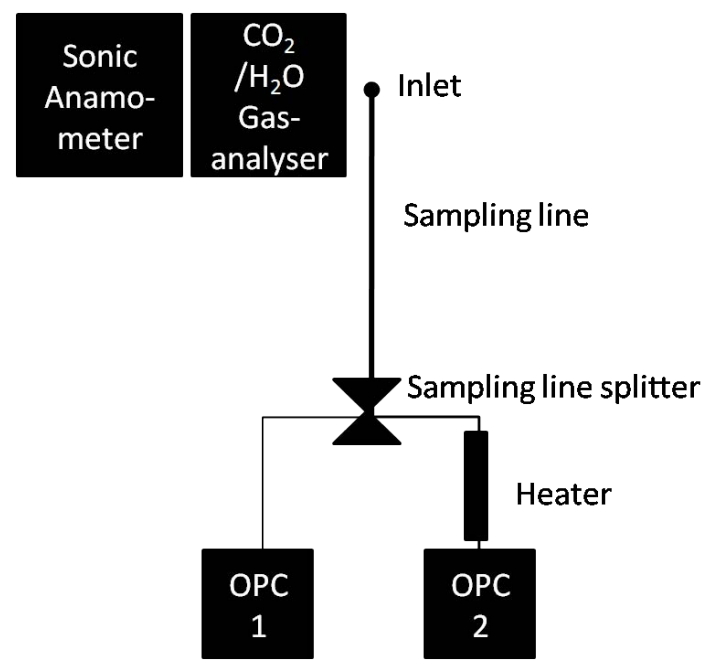

Fig. 2. Schematic of the measurement setup at Kalmgatan (tower).

The volatility in this study was measured by heating the air to either 200 or $300^{\circ} \mathrm{C}$. Table A1lists the number of individual half hour values obtained when the air entering the OPC was heated to 200 and $300{ }^{\circ} \mathrm{C}$. The unheated sampling line was always run in parallel with the heated lines. The aerosol in air heated to $200^{\circ} \mathrm{C}$ was measured in May and July 2008, and the $300^{\circ} \mathrm{C}$ data originates from May 2008 to February 2009 (with the exception of August 2008).

\subsection{Eddy covariance fluxes, corrections and errors}

The turbulent vertical aerosol number flux at the Kalmgatan tower was calculated using the eddy covariance technique. The eddy covariance (EC) technique allows us to obtain integral measurements of the amount of particles emitted from a footprint covering a relatively large urban area (approximately one square kilometer). For this study, the flux $\overline{w^{\prime} c^{\prime}}$ was calculated over periods of $30 \mathrm{~min}$. The fluctuations $w^{\prime}$ and $c^{\prime}$ were separated from the mean by linear detrending, which also removes the influence of low frequency trends. The validity of the EC technique at the Kalmgatan measurement location has been confirmed in earlier studies Mårtensson et al. (2006); Vogt et al. (2011a,b), where it was also shown, using turbulent spectra, that the measurements are within the surface boundary layer during daytime. The fluxes have been corrected for the limited time response of the sensor and attenuation of turbulent fluctuations in the sampling line. The response time constant $\tau$ for the OPC instrument in combination with the lag of air in the and sampling line was estimated to be $1.0 \mathrm{~s}$ using transfer equations for damping of particle fluctuations in laminar flow (Lenschow and Raupach, 1991) and in a sensor (Horst, 1997). The typical magnitude of these corrections varied, with the uncorrected aerosol fluxes being between 12 to $32 \%$ less for the unheated cases and between 17 to $35 \%$ less for 

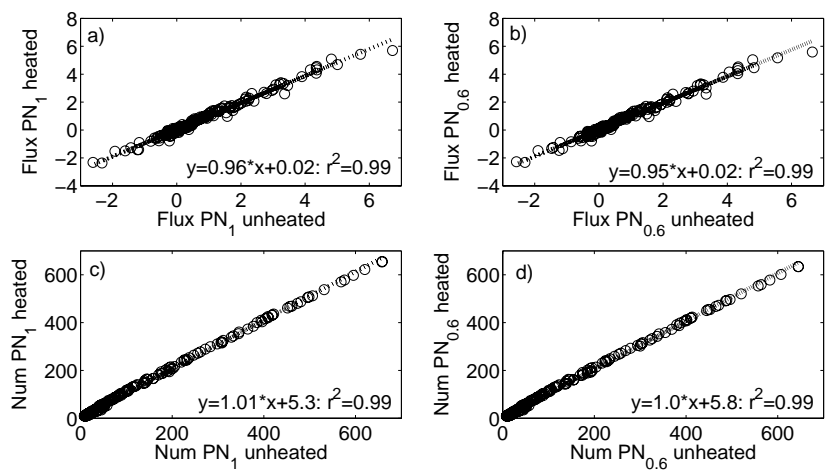

Fig. 3. Correlation between the two OPCs for ambient temperatures (a) particle number flux $\mathrm{PN}_{1}$ (b) particle number flux $\mathrm{PN}_{0.6}$ (c) particle number concentration $\mathrm{PN}_{1}$ (d) particle number concentration $\mathrm{PN}_{0.6}$.

periods when the aerosol was heated. The variations can be attributed to differences in wind speed and stability conditions. The aerosol fluxes and concentrations were also corrected for particle losses to the walls in the sampling line, which resulted in particle losses of $5 \%$ for the largest size class in the OPC ( 2 to $2.5 \mu \mathrm{m} D_{\mathrm{p}}$ ), and much less in the smaller sizes. Counting errors are the dominant error in the number concentration. These were estimated to be $0.11 \%$ for the smallest size class $\left(0.25 \mu \mathrm{m} D_{\mathrm{p}}\right)$ and $4.8 \%$ for the largest size class $\left(2.5 \mu \mathrm{m} D_{\mathrm{p}}\right)$. The corresponding median relative counting error in the aerosol flux was $15 \%$ for the smallest and largest OPC sizes with a peak of $35 \%$ for $0.7 \mu \mathrm{m} D_{\mathrm{p}}$ (Vogt et al., 2011a). In this study, the relative counting error for the integrated airborne particulate number flux less than $0.6 \mu \mathrm{m} D_{\mathrm{p}}\left(\mathrm{PM}_{0.6}\right)$ was estimated to be $5 \%$ for the unheated case, $12 \%$ when the aerosol was heated to $200{ }^{\circ} \mathrm{C}$ and $9.5 \%$ when the aerosol was heated to $300^{\circ} \mathrm{C}$. The measured $\mathrm{CO}_{2}$ flux was corrected for variations in air density due to fluctuations in water vapor and heat fluxes in accordance with Webb et al. (1980). This resulted in a maximum correction around noon for $\mathrm{CO}_{2}$ flux of $37 \%$. For more details see Vogt et al. (2011a).

\subsection{Emission factors based on the $\mathrm{NO}_{\mathrm{x}}$ scaling method}

As described previously, $\mathrm{BC}$ and $\mathrm{NO}_{\mathrm{x}}$ concentrations were measured simultaneously in the street canyon and at rooftop. The ratio of the concentration difference between street and roof-top can be used as a measure of the emissions due to the road traffic on the street (e.g., Ketzel et al., 2003). If the emission factor for $\mathrm{NO}_{\mathrm{x}}$ is known, the emission factor of $\mathrm{BC}$ can be estimated by multiplying the $\mathrm{NO}_{\mathrm{x}}$ emission factor with the ratio of the $\mathrm{BC} / \mathrm{NO}_{\mathrm{x}}$ concentration increment. This method assumes that the dispersion of the emitted particles is similar to $\mathrm{NO}_{\mathrm{x}}$ dispersion. This is justified by the fact that the timescale for deposition of particles is several hours, much longer than the timescale for mixing and dilu- tion, which makes it reasonable to assume that differences in deposition of $\mathrm{NO}_{\mathrm{x}}$ and particles have a minor influence. This method has been successfully used in several earlier studies in Stockholm and elsewhere (e.g., Ketzel et al., 2003; Gidhagen et al., 2004a,b; Omstedt et al., 2005).

\subsection{Traffic statistics}

The traffic statistics were obtained using a grid resolved database of hourly traffic activity expressed as vehiclekilometers per time unit. This database is part of a regional air quality management system operated by the local environmental authority in the city of Stockholm and includes all types of air pollutant sources in the counties of Stockholm and Uppsala.

\section{Results and discussion}

\subsection{OPC instrument inter-comparison and data coverage}

For the period between 4 and 8 April 2009, we compared measurements from the two OPC instruments when both were sampling unheated air. Figure 3 shows the intercomparison of the number fluxes and concentrations for airborne particulate matter less than 0.6 and $1 \mu \mathrm{m} D_{\mathrm{p}}$, which corresponds to the smallest 7 and 11 size channels of the OPCs, respectively. The comparison of the individual instrument size classes show good correlations up to size channel $13\left(1.6 \mu \mathrm{m} D_{\mathrm{p}}\right)$ which gives us confidence in applying the volatility method in the subsequent analysis of the heated data.

\subsection{Median concentration size distributions}

The median aerosol number and volume distributions for the 3 different temperatures (unheated, 200 and $300^{\circ} \mathrm{C}$ ) are shown in Fig. 4. The data were selected for the Northern sector (from $270^{\circ}$ to $90^{\circ}$ ) which is dominated by urban traffic sources (Vogt et al., 2011a,b). The median number concentration (upper and lower quartile) within the OPC size range used in this study (from 0.25 to $1 \mu \mathrm{m} D_{\mathrm{p}}$ ) was $43 \mathrm{~cm}^{3}(24.4$, $60.3)$ for the unheated OPC, $15.4 \mathrm{~cm}^{3}(12.9,21.5)$ when the incoming air was heated to $200^{\circ} \mathrm{C}$, and $14.3 \mathrm{~cm}^{3}(11.9,19.6)$ when the incoming air was heated to $300{ }^{\circ} \mathrm{C}$. A rapid decrease in number concentration with increasing particle size can be seen in Fig. 4a, b. This trend is consistent for all three temperatures. For the particle sizes $<0.7 \mu \mathrm{m} D_{\mathrm{p}}$ the highest concentrations were found for the unheated aerosol followed by the $200^{\circ} \mathrm{C}$ results, with the lowest aerosol concentrations being found in air that was heated to $300^{\circ} \mathrm{C}$. It should be noted that the measurements in air heated to $200^{\circ} \mathrm{C}$ and $300^{\circ} \mathrm{C}$ were not simultaneous (see Table A1), so one should be careful regarding conclusions based on the difference between the aerosol distributions at these two temperatures. 

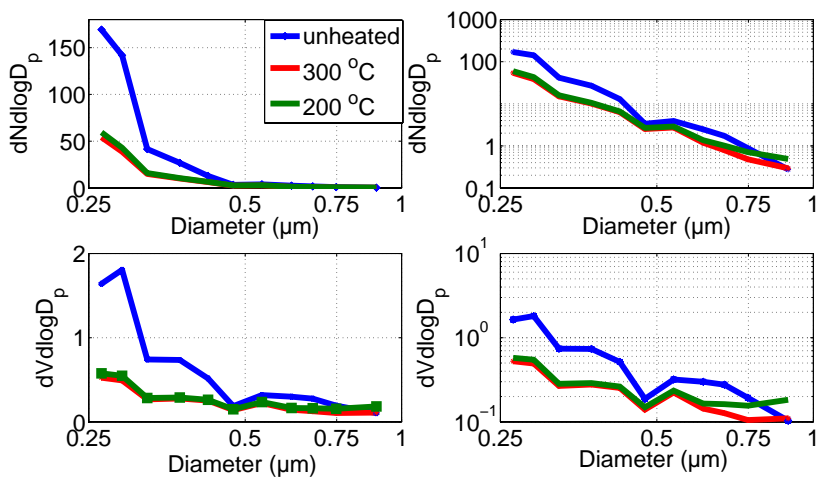

Fig. 4. Median size distributions for different OPC temperatures (a) particle number concentration (b) particle number concentration with logarithmic axes (c) particle volume concentration (d) particle volume concentration with logarithmic axes.

The largest differences in the aerosol size spectra seen in Fig. $4 \mathrm{a}, \mathrm{b}$ are not between the 200 and $300^{\circ} \mathrm{C}$ spectra, but between these and the unheated size spectra. In addition, a comparison of the unheated aerosol size distributions for the two time periods when the 200 and $300^{\circ} \mathrm{C}$ measurements were made showed no significant difference in the shape or concentration. Nonetheless, the fact that the sampling with heated air at 200 and $300{ }^{\circ} \mathrm{C}$ were not made at the same time may have had an impact on the chemical composition of the particles. The $300^{\circ} \mathrm{C}$ measurements include periods from the autumn and winter, when the fraction of non-volatile material may have been different compared to May and July (air heated to $200^{\circ} \mathrm{C}$ ). This effect was not considered in this study and so conclusions based on the difference between $200^{\circ} \mathrm{C}$ and $300^{\circ} \mathrm{C}$ measurements must be treated with some caution. In Fig. 5 the ratios of the volume concentration distributions for different temperatures are plotted, which highlights in which size channels shrinking and/or evaporation of particles takes place and emphasizes the differences seen in Fig. 4.

The ratio of the aerosol remaining after heating to $200^{\circ} \mathrm{C}$, ranges from 0.37 for particles sizes of $0.25 \mu \mathrm{m} D_{\mathrm{p}}$ to 0.8 for particles sizes of $0.75 \mu \mathrm{m} D_{\mathrm{p}}$ with a local maximum near $0.5 \mu \mathrm{m} D_{\mathrm{p}}$. For particles larger than $0.75 \mu \mathrm{m} D_{\mathrm{p}}$, the ratio is above 1 which means that larger particle volumes are present in this size bin after heating. It appears that for a temperature step of $200^{\circ} \mathrm{C}$, up to $60 \%$ of the aerosol volume disappears for the smallest sizes $\left(<0.25 \mu \mathrm{m} D_{\mathrm{p}}\right)$, which means that either the particles shrank to a smaller size, below the lower size cut of the OPC, or were completely volatilized, or a combination of both effects (the first case corresponding to an internally mixed aerosol, the latter to an aerosol that is mainly externally mixed). For an incremental change in our measurements from 200 to $300^{\circ} \mathrm{C}$, volume ratios are close to 1 for the size range of 0.25 to $0.6 \mu \mathrm{m} D_{\mathrm{p}}$. For larger sizes, the ratio decreases, indicating that particles are shrinking or disappearing completely through evaporation

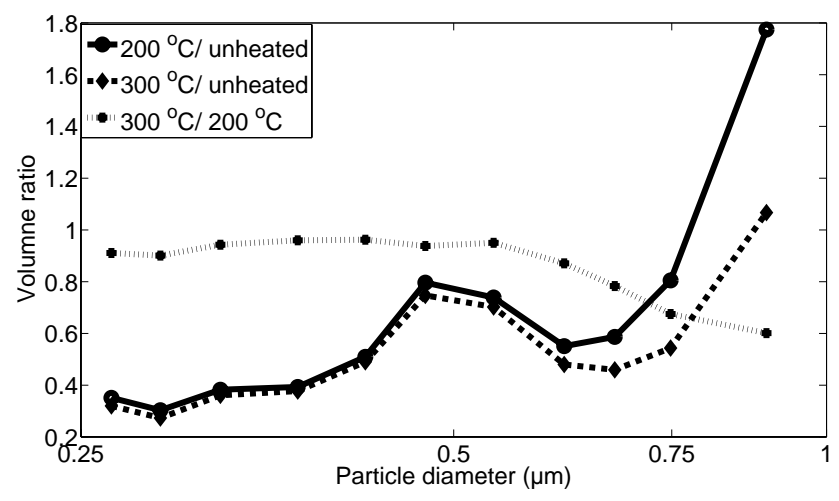

Fig. 5. Volume ratio distribution for different temperature increments.

of semi-volatile compounds. This implies that almost the entire semi-volatile fraction below $0.6 \mu \mathrm{m} D_{\mathrm{p}}$ was already lost at temperatures below $200^{\circ} \mathrm{C}$. Several volatility studies have determined specific evaporation temperature ranges for organic matter and inorganic matter (Pinnick et al., 1987; O'Dowd et al., 1997). Critical temperatures for important semi-volatile chemical compounds $\left(\mathrm{H}_{2} \mathrm{SO}_{4}\right.$ and the more volatile organic compounds) lie between $80^{\circ} \mathrm{C}$ and $120^{\circ} \mathrm{C}$. Semi-volatile organics and ammonium sulfate and bisulfate have critical temperature ranges around $180-240^{\circ} \mathrm{C}$. Above $300{ }^{\circ} \mathrm{C}$ the refractory part of the aerosol consists of elemental carbon, dust, metals, and sea salt. For urban aerosols, many studies have shown that particles smaller than $0.1 \mu \mathrm{m} D_{\mathrm{p}}$ are typically externally-mixed (Sakurai et al., 2003; Kittelson et al., 2004). The larger diameter $(>0.2 \mu \mathrm{m})$ particles are usually more aged and therefore internal mixtures of organic and inorganic compounds are more common (e.g., Alfarra et al., 2004; Zhang et al., 2004, 2007; Bein et al., 2005).

\subsection{Chemical composition}

The chemical composition of $\mathrm{PM}_{1}$ samples was investigated in order to assist in the interpretation of the observed heated aerosol population from the tower measurements. The $\mathrm{PM}_{1}$ concentration measured at the roof-top site (Torkel Knutssonsgatan) was on average $8.1 \mu \mathrm{g} \mathrm{m}^{3}$. The largest contribution to the total $\mathrm{PM}_{1}$ mass was attributed to $46.5 \%$ water insoluble soil elements (mainly oxides of $\mathrm{Fe}, \mathrm{Al}, \mathrm{Ca}, \mathrm{Si}$ and K), see Fig. 6.

Water soluble soil elements ( $\mathrm{Mg}, \mathrm{Ca}, \mathrm{Fe}, \mathrm{Al})$ account for $11 \%$ of the total $\mathrm{PM}_{1}$ mass, sulfate for $6.4 \%$, sea salt $3.6 \%$, ammonium $2.8 \%$, nitrate $1.9 \%$, and the remaining $0.4 \%$ comprised of other analysed elements. The carbonaceous compounds (EC, OC) were not explicitly measured, but are expected to constitute a large fraction of unidentified particulate material $(27 \%)$. Zhang et al. (2007) showed that inorganic components (mostly sulfate, nitrate and ammonium) and a large variety of organic species dominated the mass of fine particulate material measured in cities (e.g. Edinburgh, 

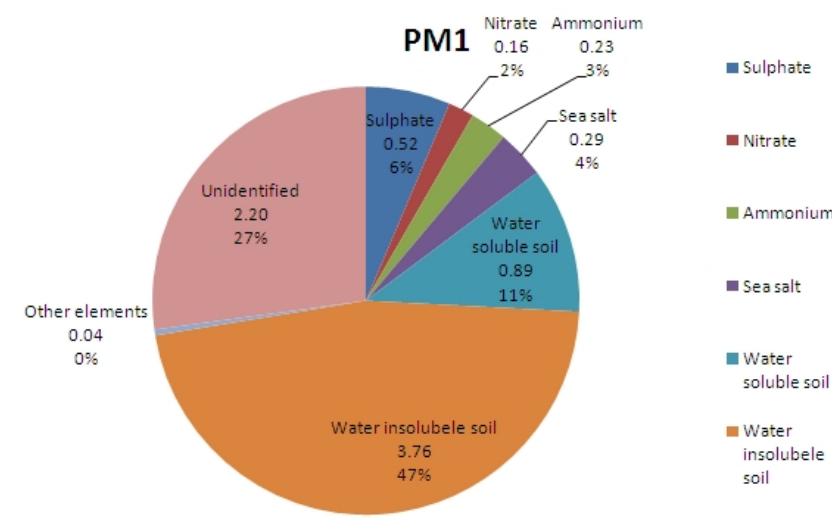

Fig. 6. Chemical composition of $\mathrm{PM}_{1}$ measured at Hornsgatan.

Mexico City, Manchester). As noted above, a large fraction of the unidentified mass $\left(2.2 \mu \mathrm{g} \mathrm{m}^{3}\right)$ is likely to be carbonaceous material. The median (25th and 75th percentile) BC concentrations (measured by light absorption) over the measurement period were $0.67 \mu \mathrm{g} \mathrm{m}^{3}\left(0.53,0.89 \mu \mathrm{g} \mathrm{m}^{3}\right)$ for the rooftop site. Most of this BC concentration is due to elemental carbon (EC) as shown by comparison with EC analysis based on thermo-optical carbon analysis (for details see Krecl et al., 2011). This BC corresponds to $30 \%$ of the missing mass, the remaining $1.5 \mu \mathrm{g} \mathrm{m}^{3}$ being attributed to organic carbon. In order to better understand in which particle size range the $\mathrm{BC}$ mass was most frequently observed, we correlated the $\mathrm{BC}$ mass against particle number concentrations in different size classes as measured by the OPC at Hornsgatan. Figure 7 shows the correlation coefficients for BC mass against number concentrations for individual size bins between 0.25 and $1 \mu \mathrm{m} D_{\mathrm{p}}$. With increasing diameter the correlation coefficient decreases. A clear drop in the correlation coefficient can be seen for size classes larger than $0.6 \mu \mathrm{m} D_{\mathrm{p}}$. A similar correlation was seen in Augsburg, Germany where the refractive core (heated to $300^{\circ} \mathrm{C}$ ) of the aerosol in the size range of $<0.80 \mu \mathrm{m} D_{\mathrm{p}}$ was compared to BC mass (Birmili et al., 2010). Krecl et al. (2011) showed that the BC concentration at sites dominated by traffic emissions (including Hornsgatan) is highly correlated with $\mathrm{NO}_{\mathrm{x}}$, which can be considered a tracer of traffic exhaust. These results suggest that the $\mathrm{BC}$ and refractive particles in the size range $<0.6 \mu \mathrm{m} D_{\mathrm{p}}$ mainly originate from traffic exhaust. We have also studied the correlation coefficients between the heated, number size distributions from the tower measurements and the black carbon mass from the roof measurements. The correlation coefficients obtained are less to those obtained when comparing $\mathrm{BC}$ and number concentrations at the street site $\left(r^{2}=0.27, r^{2}=0.43\right.$ for tower and street respectively). This suggests that the association between $\mathrm{BC}$ and the number concentration in the size range $<0.6 \mu \mathrm{m} D_{\mathrm{p}}$ found at roof level survives the vertical transport and applies to the tower level as well.

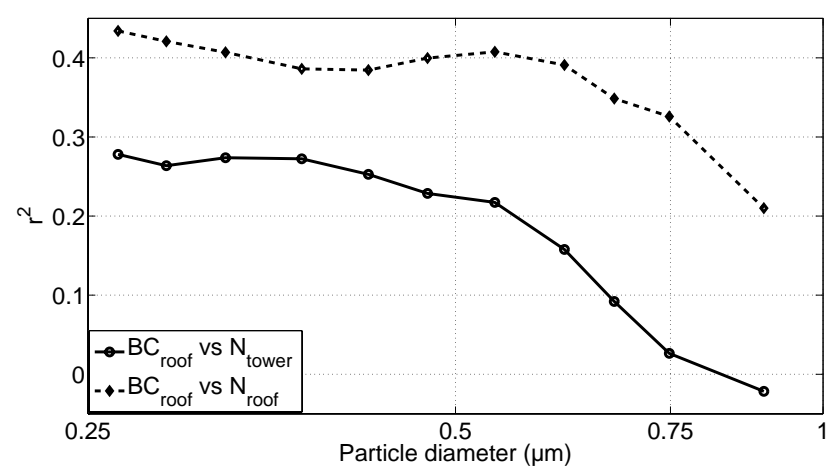

Fig. 7. Correlation coefficients between; BC concentrations measured on roof level with size resolved number concentration on roof level (dashed line); heated, size resolved number concentration on tower level (solid line).

\subsection{Emission factors}

The results presented so far regarding the aerosol $<0.6 \mu \mathrm{m}$ $D_{\mathrm{p}}$ motivates us to consider the emissions in this size range.

Mass emission factors (EF) for the heated aerosol (heated to $300{ }^{\circ} \mathrm{C}$ ) in the size range of 0.25 to $0.6 \mu \mathrm{m} D_{\mathrm{p}}$ (hereafter referred to as $\mathrm{RPM}_{0.6}$ ) were derived using the same approach as Vogt et al. (2011b), i.e. using the $\mathrm{CO}_{2}$ flux as a tracer of road traffic fossil fuel combustion. A linear fit between particle number flux and $\mathrm{CO}_{2}$ flux was used to determine an emission factor (simply the slope of the linear fit) in units of particles $\mathrm{mmol}^{-1} \mathrm{CO}_{2}$. Only the most traffic intense Northeastern sector $\left(0-90^{\circ}\right)$ was included in the analysis to minimize the effect of other (non-traffic) sources of both $\mathrm{CO}_{2}$ and particles (see Vogt et al., 2011b). By assuming a particle density of $1600 \mathrm{~kg} \mathrm{~m}^{3}$ Pitz et al. (2003) and using the particle sizes from the OPC, mass related emission factors can be calculated. The density of $1600 \mathrm{~kg} \mathrm{~m}^{3}$ was retained in this study so the emission factors for $\mathrm{RPM}_{0.6}$ are consistent with the EFs from Vogt et al. (2011b).

$\mathrm{BC}$ emission factors $\left(\mathrm{EF}_{\mathrm{BC}}\right)$ at Hornsgatan have also been calculated using the $\mathrm{NO}_{\mathrm{x}}$ scaling method (as described in the methods section above). Figure $8 \mathrm{a}-\mathrm{c}$ show the diurnal variations of the concentration of $\mathrm{BC}, \mathrm{NO}_{\mathrm{x}}$, and the derived $\mathrm{EF}_{\mathrm{BC}}$ based on the $\mathrm{NO}_{\mathrm{x}}$ scaling method. Figure 8d-f show the fluxes of particle mass, $\mathrm{CO}_{2}$ and the mass emission factor for $\mathrm{RPM}_{0.6}\left(\mathrm{EF}_{0.6}\right.$ from the tower (based on the eddy correlation technique). The diurnal cycle of $\mathrm{BC}$ concentration spans from $0.5 \mu \mathrm{g} \mathrm{m}{ }^{3}$ during night to around $3 \mu \mathrm{g} \mathrm{m}^{3}$ in the late afternoon. The diurnal pattern is similar for $\mathrm{NO}_{\mathrm{x}}$, with low values of about $35 \mu \mathrm{g} \mathrm{m}^{3}$ found in the early morning and high values in the late afternoon of around $170 \mu \mathrm{g} \mathrm{m} \mathrm{m}^{3}$. These diurnal patterns are consistent with traffic activity pattern observed at Hornsgatan by Krecl et al. (2011), who found a correlation coefficient of 0.78 between $\mathrm{BC}$ and $\mathrm{NO}_{\mathrm{x}}$. The heated particle number flux $\left(0.25\right.$ to $\left.0.6 \mu \mathrm{m} D_{\mathrm{p}}\right)$ shows a broad peak between 07:00 LT to 19:00 LT. The source strength varies 

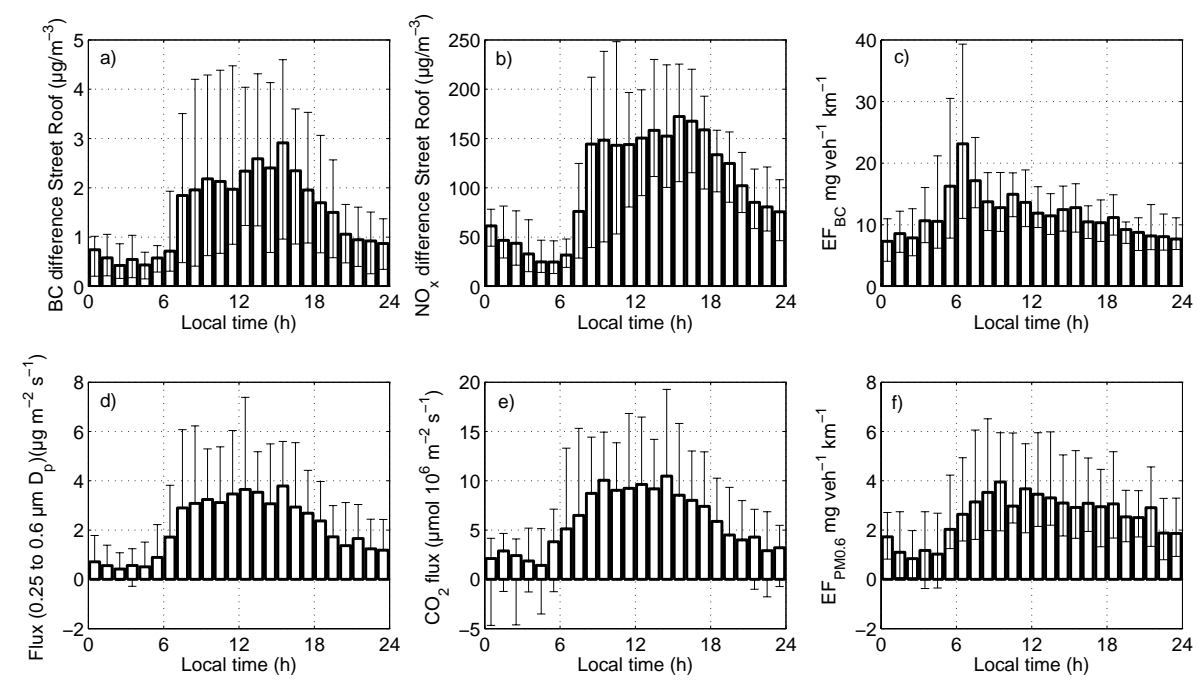

Fig. 8. Median diurnal cycles of (a) $\mathrm{BC}$ concentration (b) $\mathrm{NO}_{\mathrm{x}}$ concentrations (c) $\mathrm{BC}$ emission factor (d) particle number flux, (e) $\mathrm{CO}_{2}$ flux, (f) mass emission factor EFRPM $\mathrm{E}_{0.6}$. The vertical bars represent the 25 th and 75 th percentile.

between $2 \times 10^{4}$ particles $\mathrm{m}^{-2} \mathrm{~s}^{-1}$ at night to about $12 \times 10^{5}$ particles $\mathrm{m}^{-2} \mathrm{~s}^{-1}$ around noon. The diurnal cycle of $\mathrm{CO}_{2}$ flux is similar to particle flux with the highest emission of $11 \mu \mathrm{mol} \mathrm{m}{ }^{-2} \mathrm{~s}^{-1}$ in early afternoon and lowest emission during night $\left(2 \mu \mathrm{mol} \mathrm{m}^{-2} \mathrm{~s}^{-1}\right)$ (Fig. $8 \mathrm{~d}$, e).

The calculated emission factors for $\mathrm{BC}$ at Hornsgatan range from $8 \mathrm{mgveh}^{-1} \mathrm{~km}^{-1}$ to peak values of $23 \mathrm{mg} \mathrm{veh}^{-1} \mathrm{~km}^{-1}$. The $\mathrm{RPM}_{0.6}$ emission factors obtained from the tower measurements range from $1 \mathrm{mg} \mathrm{veh}^{-1} \mathrm{~km}^{-1}$ to approximately $4 \mathrm{mg} \mathrm{veh}^{-1} \mathrm{~km}^{-1}$. Interestingly, no clear morning rush hour peak is observed from the tower measurements. This diurnal EF pattern is consistent with the diurnal pattern of heavy duty traffic, which has been seen before in the earlier analysis of the continuous measurements with unheated air (Vogt et al., 2011b). The average mass emission factors for the $\mathrm{RPM}_{0.6}$ were found to be $2.4 \pm 1.4 \mathrm{mg} \mathrm{veh}^{-1} \mathrm{~km}^{-1}$ based on $\mathrm{CO}_{2}$ emissions and $2.5 \pm 1.4 \mathrm{mg} \mathrm{veh}^{-1} \mathrm{~km}^{-1}$ (see Table A2) based on traffic counts. For comparison, the median BC emission factor for Hornsgatan is $11.1 \mathrm{mg} \mathrm{veh}^{-1} \mathrm{~km}^{-1}(4.3,19.7)$. The higher emission factor for $\mathrm{BC}$ compared to $\mathrm{RPM}_{0.6}$ is likely due to the fact that Hornsgatan is representative for very high emissions at a single location, whilst the EF obtained by the flux measurements represents the average of a larger area with more modest emissions. The $\mathrm{BC}$ emission factor is within the range of the values reported in the literature (Olivares et al., 2008; Imhof et al., 2005). There are no previously reported emission factors for $\mathrm{RPM}_{0.6}$.

In previous studies combining aerosol fluxes with traffic statistics (Mårtensson et al., 2006; Vogt et al., 2011b) we have been able to derive separate emission factors for heavy and light duty traffic. For the total particle number $D_{\mathrm{p}}>10 \mathrm{~nm}$, Mårtensson et al. (2006) found that the heavy duty traffic dominate the emissions. Vogt et al. (2011b) found for particles in the range 0.8 to $2.5 \mu \mathrm{m} D_{\mathrm{p}}$ that mass EFs for HDV are 30 times larger than for LDV, indicating that trucks and buses more efficiently resuspending supermicron road dust.

However, for the $\mathrm{RPM}_{0.6}$ in the 0.25 to $0.6 \mu \mathrm{m} D_{\mathrm{p}}$ size range, the HDV EF is only about twice as high as the LDV $\mathrm{EF}$, and the uncertainties are so large that the difference is not significant. The LDV EF derived from the multiple linear regression is approximately the same as the overall EF from ordinary linear regression. This indicates that for $\mathrm{RPM}_{0.6}$ emissions, the type of vehicle is less important and that LDV due to their larger numbers, dominate the overall emissions.

\section{Conclusions}

Size-resolved, vertical aerosol number fluxes of particles betwenn 0.25 and $1.0 \mu \mathrm{m} D_{\mathrm{p}}$ were measured with the eddy covariance method from a $105 \mathrm{~m}$ high tower over an urban site in central Stockholm, Sweden. The OPCs, which were used to determine the particle fluxes, were equipped with a system to heat the sampled air. When the air was heated to $200{ }^{\circ} \mathrm{C}$ or $300{ }^{\circ} \mathrm{C}$, a considerable fraction of the aerosol concentration was lost. Up to $200^{\circ} \mathrm{C}$, approximately $60 \%$ of the aerosol volume was lost for the smallest OPC size classes $\left(0.25 \mu \mathrm{m} D_{\mathrm{p}}\right)$ whilst only $20 \%$ of the particle volume is lost for particles sizes of $0.75 \mu \mathrm{m} D_{\mathrm{p}}$. Further heating from 200 to $300{ }^{\circ} \mathrm{C}$ appears to have caused very little additional losses up to $0.6 \mu \mathrm{m} D_{\mathrm{p}}$. For larger sizes between 0.6 and $1 \mu \mathrm{m} D_{\mathrm{p}}$ the volume ratios start to decrease indicating losses of less semi-volatile compounds.

Chemical analysis showed that the inorganic fraction of sulfate, nitrate, ammonium and sea salt only accounts for approximately $15 \%$ of the $\mathrm{PM}_{1}$ total mass, water soluble soil 
$11 \%$ whilst the largest mass fraction was attributed to water insoluble soil $(46.5 \%)$. Carbonaceous compounds were at the most about one quarter of the mass. Of the missing mass, $\mathrm{BC}$ could explain about $30 \%$ the rest likely being organic compounds. The $\mathrm{BC}$ concentration at roof level and the refractory aerosol number at tower level $\left(\right.$ at $300^{\circ} \mathrm{C}$ ) for the size range below $0.6 \mu \mathrm{m} D_{\mathrm{p}}$ was observed to be correlated $\left(r^{2}=0.27\right)$. In addition, the average diurnal cycles of the BC emission at a street in central Stockholm and the refractory $\left(\mathrm{RPM}_{0.6}\right)$ aerosol fluxes at tower level show distinct and similar diurnal variations, indicating a traffic origin. We have estimated the emission factors for the refractory aerosol below $0.6 \mu \mathrm{m} D_{\mathrm{p}}$ using the aerosol fluxes, both via the $\mathrm{CO}_{2}$ flux method and using traffic statistics. Both methods result in an EF of approximately $2.4 \pm 1.4 \mathrm{mg} \mathrm{veh}^{-1} \mathrm{~km}^{-1}$.

It is clear from this study that the combination of eddy covariance and volatility measurements offers a proxy for full chemical characterization of particle emissions. However for future studies it would be valuable to include chemical specification directly in the flux measurements, using e.g. aerosol sampling on filters/impactors on hourly time scale using the relaxed eddy accumulation method. Information on the emissions of different chemical compounds would yield valuable information on the contribution of different sources. Furthermore, it would also be of great value if size resolved aerosol flux measurements could be made in the size range below $0.25 \mu \mathrm{m} D_{\mathrm{p}}$, where the majority of the aerosol number is emitted (Mårtensson et al., 2006). While it is evident that continuous measurements for a full annual cycle has provided very valuable information on changes in emissions over different seasons, these type of measurements must be maintained for several years if we are to be able to follow changes in emissions due to changes in vehicle population, fuel usage, engine technology, mitigation of air quality by restrictions on traffic such as restrictions against studded tires or traffic tolls, changes in economy or climate changes.

\section{Appendix A}

Table A1. Overview of individual half hour measurements made during the campaign. The unheated sampling line was running at all times in parallel to the heated. The following abbreviations are used $T$ : Temperature $\left({ }^{\circ} \mathrm{C}\right)$ of heated air; $N$ : total number of half hours; $N_{\mathrm{N}}$ : number of half hours of which are in Northern sector (270-90 $) ; N_{\mathrm{M}}$ : months with data.

\begin{tabular}{llll}
\hline$T$ & $N$ & $N_{\mathrm{N}}$ & $N_{\mathrm{M}}$ \\
\hline 200 & 1800 & 1003 & May 08, Jul 08 \\
300 & 9250 & 3729 & May 08-Feb 09 no Aug 08 \\
\hline
\end{tabular}

Table A2. Comparison between the different attempts to find a source parameterization $(F)$ for refractory aerosol particles smaller than $0.6 \mu \mathrm{m} D_{\mathrm{p}}$. The traffic activity used is the mean daily traffic activity from (Monday-Friday, 24 values) in the NE sector over an area of $1 \mathrm{~km} \times 1 \mathrm{~km}$, (TA, traffic activity, light duty vehicles (LDV) and heavy-duty vehicles(HDV)). The following abbreviations are used (LR: linear regression (Equation $F=\mathrm{EF}_{\text {Fleet mix }} \mathrm{TA}+F_{0}$ ); MLR: multiple linear regression (Equation $\left.\left.F=\mathrm{EF}_{\mathrm{LDV}} \mathrm{TA}_{\mathrm{LDV}}+\mathrm{EF}_{\mathrm{HDV}} \mathrm{TA}_{\mathrm{HDV}}+F_{0}\right)\right) ; M_{\mathrm{CO}_{2}}$ : $\mathrm{EF}$ based on $\mathrm{CO}_{2}$ emission fluxes (Equation $F=\mathrm{EF}_{\text {Fleet mix }} \mathrm{TA}$ ).

\begin{tabular}{|c|c|c|c|c|}
\hline Method & $R^{2}$ & $\begin{array}{l}\text { Emission } \\
\text { (mg veh }^{-}\end{array}$ & $\begin{array}{l}\text { factor } \\
\left.\mathrm{km}^{-1}\right)\end{array}$ & $\begin{array}{l}\text { Intercept } \\
\left(\mathrm{mg} \mathrm{m}^{-2} \mathrm{~s}^{-1}\right)\end{array}$ \\
\hline \multirow[t]{2}{*}{ LR } & & $\mathrm{EF}$ & & $F_{0}$ \\
\hline & 0.91 & $2.5 \pm 1.4$ & & $0.7 \pm 0.3$ \\
\hline \multirow[t]{2}{*}{ MLR } & & $\mathrm{EF}_{\mathrm{LDV}}$ & $\mathrm{EF}_{\mathrm{HDV}}$ & \\
\hline & 0.91 & 2.3 & $5.1 \pm 8$ & $0.7 \pm 0.4$ \\
\hline$M_{\mathrm{CO}_{2}}$ & 0.79 & $2.4 \pm 1.4$ & & \\
\hline
\end{tabular}

Acknowledgements. We would like to thank the Swedish Research Council for Environment, Agricultural Science and Spatial Planning (FORMAS) (the TEA project, Traffic Emissions of Aerosols) and the Swedish Research Council (VR) for supporting this project. We also acknowledge Leif Bäcklin and Kai Rosman for technical assistance and Peter Tunved for helpful discussions. We also like to thank Telia Sonera for use of the communication tower.

Edited by: M. Kulmala

\section{References}

Alfarra, M. R., Coe, H., Allan, J. D., Bower, K. N., Boudries, H., Canagaratna, M. R., Jimenez, J. L., Jayne, J. T., Garforth, A. A., Li, S.-M., and Worsnop, D. R.: Characterization of urban and rural organic particulate in the Lower Fraser Valley using two Aerodyne Aerosol Mass Spectrometers, Atmos. Environ., 38, 5745-5758, 2004.

Bein, K., Zhao, Y., Wexler, A., and Johnston, M.: Speciation of size-resolved individual ultrafine particles in Pittsburgh, Pennsylvania, J. Geophys. Res.-Atmos., 110, D15s09, doi:10.1029/2003jd004378, 2005.

Birmili, W., Heinke, K., Pitz, M., Matschullat, J., Wiedensohler, A., Cyrys, J., Wichmann, H.-E., and Peters, A.: Particle number size distributions in urban air before and after volatilisation, Atmos. Chem. Phys., 10, 4643-4660, doi:10.5194/acp-10-46432010, 2010.

Chow, J. C., Watson, J. G., Mauderly, J. L., Costa, D. L., Wyzga, R. E., Vedal, S., Hidy, G. M., Altshuler, S. L., Marrack, D., Heuss, J. M., Wolff, G. T., Pope, III, C. A., and Dockery, D. W.: Health effects of fine particulate air pollution: Lines that connect, J. Air Waste Manage. Assoc., 56, 1368-1380, 2006.

Clarke, A., Shinozuka, Y., Kapustin, V., Howell, S., Huebert, B., Doherty, S., Anderson, T., Covert, D., Anderson, J., Hua, X., Moore, K., McNaughton, C., Carmichael, G., and Weber, R.: Size distributions and mixtures of dust and black carbon aerosol 
in Asian outflow: Physiochemistry and optical properties, J. Geophys. Res.-Atmos., 109, D07S05, doi:10.1029/2004JD004708, 2004.

Gidhagen, L., Johansson, C., Ström, J., Kristensson, A., Swietlicki, E., Pirjola, L., and Hansson, H. C.: Model simulation of ultrafine particles inside a road tunnel, Atmos. Environ., 37, 2023-2036, 2003.

Gidhagen, L., Johansson, C., Langner, J., and Olivares, G.: Simulation of $\mathrm{NO}_{\mathrm{x}}$ and ultrafine particles in a street canyon in Stockholm, Sweden, Atmos. Environ., 38, 2029-2044, 2004a.

Gidhagen, L., Johansson, C., Omstedt, G., Langner, J., and Olivares, G.: Model simulations of $\mathrm{NO}_{\mathrm{x}}$ and ultrafine particles close to a Swedish highway, Environ. Sci. Technol., 38, 6730-6740, 2004b.

Hansen, J. and Nazarenko, L.: Soot climate forcing via snow and ice albedos, P. Natl. Acad. Sci. USA, 101, 423-428, 2004.

Hoppel, W., Fitzgerald, J., Frick, G., Larson, R., and Mack, E.: Aerosol Size Distributions And Optical-Properties Found In The Marine Boundary-Layer Over The Atlantic-Ocean, J. Geophys. Res.-Atmos., 95, 3659-3686, 1990.

Horst, T.: A simple formula for attenuation of eddy fluxes measured with first-order-response scalar sensors, Bound.-Lay. Meteorol., 82, 219-233, 1997.

Imhof, D., Weingartner, E., Ordonez, C., Gehrigt, R., Hill, N., Buchmann, B., and Baltensperger, U.: Real-world emission factors of fine and ultrafine aerosol particles for different traffic situations in Switzerland, Environ. Sci. Technol., 39, 8341-8350, 2005.

Johansson, C.: Påverkan på partikelhalter av trädplantering längs gator i Stockholm, Tech. rep., Miljöförvaltningen, 2009.

Ketzel, M., Wahlin, P., Berkowicz, R., and Palmgren, F.: Particle and trace gas emission factors under urban driving conditions in Copenhagen based on street and roof-level observations, Atmos. Environ., 37, 2735-2749, 2003.

Ketzel, M., Omstedt, G., Johansson, C., Duering, I., Pohjolar, M., Oettl, D., Gidhagen, L., Wahlin, P., Lohmeyer, A., Haakana, M., and Berkowicz, R.: Estimation and validation of PM2.5/PM10 exhaust and non-exhaust emission factors for practical street pollution modelling, Atmos. Environ., 41, 9370-9385, 2007.

Kittelson, D. B., Watts, W. F., Johnson, J. P., Remerowki, M. L., Ische, E. E., Oberdörster, G., Gelein, R. M., Elder, A., Hopke, P. K., Kim, E., Zhao, W., Zhou, L., and Jeong, C.-H.: On-road exposure to highway aerosols. 1. Aerosol and gas measurements, Inhalation Toxicology, 16 Suppl 1, 31-39, 2004.

Krecl, P., Stroem, J., and Johansson, C.: Carbon content of atmospheric aerosols in a residential area during the wood combustion season in Sweden, Atmos. Environ., 41, 6974-6985, 2007.

Krecl, P., Targino, A. C., and Johansson, C.: Spatiotemporal distribution of light-absorbing carbon and its relationship to other atmospheric pollutants in Stockholm, Atmos. Chem. Phys., 11, 11553-11567, doi:10.5194/acp-11-11553-2011, 2011.

Kuhn, T., Biswas, S., and Sioutas, C.: Diurnal and seasonal characteristics of particle volatility and chemical composition in the vicinity of a light-duty vehicle freeway, Atmos. Environ., 39, 7154-7166, 2005.

Lenschow, D. and Raupach, M.: The attenuation of fluctuations in scalar concentrations through sampling tubes , J. Geophys. Res.Atmos., 96, 15259-15268, 1991.

Mar, T. F., Norris, G. A., Koenig, J. Q., and Larson, T. V.: Associations between Air Pollution and Mortality in Phoenix, 19951997, Environ Health Perspect, 108, 347-353, 2000.
Mårtensson, E. M., Nilsson, E. D., Buzorius, G., and Johansson, C.: Eddy covariance measurements and parameterisation of traffic related particle emissions in an urban environment, Atmos. Chem. Phys., 6, 769-785, doi:10.5194/acp-6-769-2006, 2006.

NRC: Research Priorities for Airborne Particulate Matter: IV. Continuing Research Progress. Committee on Research Priorities for Airborne Particulate Matter., Tech. rep., National Research Council, Washington, DC, 2004.

O'Dowd, C. and Smith, M.: Physicochemical Properties Of Aerosols Over The Northeast Atlantic - Evidence For WindSpeed-Related Submicron Sea-Salt Aerosol Production, J. Geophys. Res.-Atmos., 98, 1137-1149, 1993.

O’Dowd, C. D., Smith, M. H., Consterdine, I. E., and Lowe, J. A.: Marine aerosol, sea-salt, and the marine sulphur cycle: a short review, Atmos. Environ., 31, 73-80, 1997.

Olivares, G., Strom, J., Johansson, C., and Gidhagen, L.: Estimates of black carbon and size-resolved particle number emission factors from residential wood burning based on ambient monitoring and model simulations, J. Air Waste Manage. Assoc., 58, 838848, 2008.

Omstedt, G., Bringfelt, B., and Johansson, C.: A model for vehicleinduced non-tailpipe emissions of particles along Swedish roads, Atmos. Environ., 39, 6088-6097, 2005.

Orsini, D. A., Wiedensohler, A., and Stratmann, F.: A New Volatility Tandem Differential Mobility Analyzer to Measure the Volatile Sulfuric Acid Aerosol Fraction, J. Atmos. Ocean. Tech., 16, 760-772, 1999.

Peel, J. L., Metzger, K. B., Klein, M., Flanders, W. D., Mulholland, J. A., and Tolbert, P. E.: Ambient Air Pollution and Cardiovascular Emergency Department Visits in Potentially Sensitive Groups, American Journal of Epidemiology, 165, 625-633, 2007.

Pinnick, R., Jennings, S., and Fernandez, G.: Volatility of Aerosols in the Arid Southwestern United-States, J. Atmos. Sci., 44, 562576, 1987.

Pitz, M., Cyrys, J., Karg, E., Wiedensohler, A., Wichmann, H., and Heinrich, J.: Variability of apparent particle density of an urban aerosol, Environ. Sci. Technol., 37, 4336-4342, 2003.

Pratt, K. A. and Prather, K. A.: Real-Time, Single-Particle Volatility, Size, and Chemical Composition Measurements of Aged Urban Aerosols, Environ. Sci. Technol., 43, 8276-8282, 2009.

Putaud, J., Raes, F., Van Dingenen, R., Bruggemann, E., Facchini, M., Decesari, S., Fuzzi, S., Gehrig, R., Huglin, C., Laj, P., Lorbeer, G., Maenhaut, W., Mihalopoulos, N., Mulller, K., Querol, X., Rodriguez, S., Schneider, J., Spindler, G., ten Brink, H., Torseth, K., and Wiedensohler, A.: European aerosol phenomenology-2: chemical characteristics of particulate matter at kerbside, urban, rural and background sites in Europe, Atmos. Environ., 38, 2579-2595, 2004.

Sakurai, H., Park, K., McMurry, P., Zarling, D., Kittelson, D., and Ziemann, P.: Size-dependent mixing characteristics of volatile and nonvolatile components in diesel exhaust aerosols, Environ. Sci. Technol., 37, 5487-5495, 2003.

Södin, A., Ferm, M., Björk, A., Rahmberg, M., Gudmundsson, A., Swietlicki, E., Johansson, C., Gustafsson, M., and Blomqvist, G.: WEAREM Wear particles from road traffic - a field, laboratory and modeling study, Tech. rep., IVL Swedish Environmental Research Institute, 2009. 
Sternbeck, J., Sjodin, A., and Andreasson, K.: Metal emissions from road traffic and the influence of resuspension - results from two tunnel studies, Atmos. Environ., 36, 4735-4744, 2002.

Suglia, S. F., Gryparis, A., Schwartz, J., and Wright, R. J.: Association between traffic-related black carbon exposure and lung function among urban women, Environ. Health Perspect., 116, 1333-1337, 2008.

Vogt, M., Nilsson, E. D., Ahlm, L., Mårtensson, E. M., and Johansson, C.: Seasonal and diurnal cycles of $0.25-2.5 \mu \mathrm{m}$ aerosol fluxes over urban Stockholm, Sweden, Tellus B, 63, doi:10.1111/j.1600-0889.2011.00551.x, 2011a.

Vogt, M., Nilsson, E. D., Ahlm, L., Mårtensson, E. M., and Johansson, C.: The relationship between $0.25-2.5 \mu \mathrm{m}$ aerosol and $\mathrm{CO}_{2}$ emissions over a city, Atmos. Chem. Phys., 11, 4851-4859, doi:10.5194/acp-11-4851-2011, 2011 b.

Vogt, M., Nilsson, E. D., Ahlm, L., Mårtensson, E. M., Struthers, H., and Johansson, C.: Traffic aerosol emission velocity derived from direct flux measurements over urban Stockholm, Sweden, Atmos. Environ., 45, 5725-5731, doi:10.1016/j.atmosenv.2011.07.026, 2011c.
Webb, E., Pearman, G., and Leuning, R.: Correction of Flux Measurements for Density Effects due to Heat and Water-Vapor Transfer, Q. J. Roy. Meteorol. Soc., 106, 85-100, 1980.

Zhang, Q., Stanier, C., Canagaratna, M., Jayne, J., Worsnop, D., Pandis, S., and Jimenez, J.: Insights into the chemistry of new particle formation and growth events in Pittsburgh based on aerosol mass spectrometry, Environ. Sci. Technol., 38, 4797 4809, 2004.

Zhang, Q., Jimenez, J. L., Canagaratna, M. R., Allan, J. D., Coe, H., Ulbrich, I., Alfarra, M. R., Takami, A., Middlebrook, A. M., Sun, Y. L., Dzepina, K., Dunlea, E., Docherty, K., DeCarlo, P. F., Salcedo, D., Onasch, T., Jayne, J. T., Miyoshi, T., Shimono, A., Hatakeyama, S., Takegawa, N., Kondo, Y., Schneider, J., Drewnick, F., Borrmann, S., Weimer, S., Demerjian, K., Williams, P., Bower, K., Bahreini, R., Cottrell, L., Griffin, R. J., Rautiainen, J., Sun, J. Y., Zhang, Y. M., and Worsnop, D. R.: Ubiquity and dominance of oxygenated species in organic aerosols in anthropogenically-influenced Northern Hemisphere midlatitudes, Geophys. Res. Lett., 34, L13801, doi:10.1029/2007GL029979, 2007. 